\title{
Pengaruh Pemberian Air Kelapa Muda Terhadap Tingkat Status Hidrasi Cairan Tubuh Setelah Melakukan Aktifitas Olahraga Mahasiswa Jurusan Ilmu Keolahragaan Universitas Negeri Medan
}

\author{
Rosmaini Hasibuan \\ Correspondence: Fakultas Ilmu Keolahragaan, Universitas Negeri Medan, \\ Medan, Indonesia. \\ E-mail:
}

\begin{abstract}
ABSTRAK
Tujuan penelitian ini adalah untuk mengetahui Pengaruh Pemberian Air Kelapa Muda Terhadap Tingkat Status Hidrasi Cairan Tubuh Setelah Melakukan Aktifitas Olahraga Mahasiswa Jurusan Ilmu Keolahragaan Universitas Negeri Medan. Penelitian ini menggunakan metode eksperimen. Sampel yang digunakan berjumlah 14 orang. Sampel dibagi menjadi 2 kelompok perlakuan dengan sistem matching by paired, kelompok pertama mengkonsumsi air kelapa muda dan kelompok kedua mengkonsumsi air putih. Untuk mengetahui pengaruh pemberian air kelapa muda terhadap tingkat status hidrasi cairan tubuh maka diberikan sebanyak $500 \mathrm{ml}$ setelah melakukan aktifitas olahraga selanjutnya digunakan statistik dengan uji-t satu pihak dan untuk mengetahui perbedaan pengaruhnya digunakan uji-t dua pihak (gabungan). Hasil analisis dengan uji - menunjukkan bahwa: (1) pengujian hopotesis satu menunjukkan bahwa nilai ( $\mathrm{T}_{\text {hitung }}$ ) 2,38 selanjutnya harga tersebut dibandingkan dengan harga $\mathrm{T}_{\text {tabel }}$ dengan dk $\mathrm{n}-1(7-1=6)$, pada taraf signifikan $\alpha=0,05$ adalah 1,94 dengan demikian $t_{h}>t_{t}(2,38>1,94)$, maka thitung lebih besar dari $t_{\text {tabel. }}$ (2) pengujian hipotesis dua menunjukkan bahwa nilai $\left(\mathrm{T}_{\text {hitung }}\right) 2,09$ maka $t_{\text {hitung }}$ juga lebih besar dari $t_{\text {tabel. }}$ (3) untuk pengujian hipotesis post test ketiga menunjukkan Kriteria pengujian adalah : terima Ha jika $\mathrm{T}_{\text {hitung }}>\mathrm{T}_{\text {tabel }}$, dimana $\mathrm{T}_{\text {tabel }}$ didapat dari daftar distribusi $\mathrm{t}$ dengan $\mathrm{dk}=\left(\mathrm{n}_{1}+\mathrm{n}_{2}-2\right)$. Diperoleh bahwa $\mathrm{T}_{\text {hitung }}$ sebesar 3,31. Dari daftar tabel $\mathrm{dk}=(7+7-2)$ diperoleh bahwa $\mathrm{T}_{\text {tabel }}=1,75$. Dengan demikian $\mathrm{T}_{\text {hitung }}>$ $\mathrm{T}_{\text {tabel }}(3,31>1,75)$. Penelitian ini menyimpulkan bahwa : 1. Terdapat Pengaruh Pemberian Air Kelapa Muda Terhadap Tingkat Status Hidrasi Cairan Tubuh Setelah Melakukan Aktifitas Olahraga Mahasiswa Jurusan Ilmu Keolahragaan Universitas Negeri Medan. 2. Terdapat Pengaruh Pemberian Air Putih Terhadap Tingkat Status Hidrasi Cairan Tubuh Setelah Melakukan Aktifitas Olahraga Mahasiswa Jurusan Ilmu Keolahragaan Universitas Negeri Medan. 3. Pemberian Air Kelapa Muda Lebih Baik Pengaruhnya Terhadap Tingkat Status Hidrasi Cairan Tubuh Dibandingkan Dengan Air Putih Setelah Melakukan Aktifitas Olahraga Mahasiswa Jurusan Ilmu Keolahragaan Universitas Negeri Medan.
\end{abstract}

Kata Kunci: Air Kelapa Muda, Status Hidrasi 


\section{Pendahuluan}

Pada saat melakukan olahraga kita selalu ingin mengkonsumsi cairan, itu diakibatkan aktifitas fisik yang tinggi pada saat berolahraga akan meningkatkan suhu tubuh karena pada saat suhu tubuh meningkat akan terjadi pengeluaran energi dan elektrolit yang keluar berupa zat - zat sisa seperti keringat dan urin dari dalam tubuh, seperti yang peneliti perhatikan pada Mahasiswa Olahraga Jurusan Ilmu Keolahragaan saat mengikuti mata kuliah praktek, Mahasiswa selalu membawa ataupun membeli cairan seperti air mineral dan juga minuman produksi yang mengandung ion - ion berelektrolit, hal ini dikarenakan pada saat mengikuti mata kuliah praktek olahraga rasa haus dan keinginan untuk mengkonsumsi cairan sangatlah besar terutama pada saat aktifitas olahraga yang cukup lama, sehingga setelah meraka beraktifitas olahraga mereka langsung mengkonsumsi cairan - cairan yang bertujuan untuk mengembalikan cairan dalam tubuh agar suhu tubuh kembali normal.

Hidrasi yang disebabkan oleh hilangnya cairan dan elektrolit tubuh melalui keringat dan urin merupakan salah satu faktor yang dianggap berkontribusi sebagai penyebab kelelahan. Jika kelelahan tersebut tidak diatasi, maka akan mengganggu aktifitas fisik selanjutnya sehingga aktifitas mahasiswa ilmu keolahragaan akan terganggu jika terjadi kekurangan cairan. Hidrasi setelah aktivitas fisik sebaiknya bertujuan untuk memperbaiki kehilangan cairan yang terakumulasi selama berolahraga dan kebanyakan saat ini mahasiswa olahraga lebih memilih mengkonsumsi air mineral ataupun air kemasan yang mengandung elektrolit untuk mengembalikan status hidrasinya.

Menurut food and Agricultural Organization (1998). Ada minuman yang di konsumsi sebagai sport drink alami atau minuman olahraga yaitu air kelapa muda. Menurut dr. Peddy dalam majalah men'sHealth (2015) menyebutkan bahwa air buah kelapa mengandung Makronutrien seperti karbohidrad, protein, dan lemak sedangkan kandungan mikronutriennya berupa mineral dan Vitamin. Kemala (Dalam Dwita, 2009) mengemukakan bahwa "Air kelapa mengandung elektrolit dan glukosa yang bersifat isotonik sehingga sangat baik untuk di minum. Nilai gizi tertinggi yang terkandung dalam air kelapa ada pada kelapa yang berumur delapan bulan dan mineral tertingginya adalah kalium. Air kelapa muda ( umur delapan bulan) secara teknis merupakan minuman yang paling sehat, kaya nutrisi, mengandung glukosa, vitamin, hormon, dan mineral, serta alami tanpa bahan pengawet.Dari pernyataan tersebut dapat dipahami bahwa hasil belajar siswa masih kurang memuaskan, dengan kata lain hasil belajar siswa masih rendah. Hal itu dikarenakan dalam proses pembelajaran yang masih menggunakan model pembelajaran konvensional. Oleh karena itu siswa kurang termotivasi berkembang secara mandiri melalui penemuan dan proses berfikirnya. Hasil belajar siswa dipengaruhi oleh berbagai faktor, antara lain sebagaimana yang diungkapkan oleh Slameto (2003:54), yaitu: Faktor internal 
(faktor yang berasal dari dalam diri siswa) meliputi; minat, bakat, kreatifitas, motivasi, IQ, dan lain sebagainya. Sedangkan faktor eksternal (faktor yang berasal dari luar siswa), meliputi sarana dan prasarana, lingkungan, pendidik, buku-buku, media, metode pembelajaran dan sebagainya.

Dari pernyataan para ahli diatas dapat di katakan air kelapa muda sangatlah baik di konsumsi untuk menangani atau mengatasi hidrasi setelah melakukan aktifitas olahraga karena dalam air kelapa tedapat elektrolit dan glukosa yang sangat berguna untuk menggantikan cairan tubuh yang hilang yang diakibatkan oleh keluarnya zat zat sisa dalam tubuh berupa keringat dan urin, oleh karena itu peneliti melakukan observasi terlebih dahulu untuk mengetahui seberapa berpengaruhnya tingkat zat sisa kadar warna urin setelah melakukan aktifitas olahraga dan dalam observasi tersebut kadar warna urin orang setelah melakukan aktifitas olahraga akan terjadi perubahan warna yang di akibatkan kurangnya cairan dalam tubuh sehingga peneliti mengambil instrumen penelitian dengan mengetahui tingkat hidrasi mahasiswa olahraga dengan mengetahui tingkat kadar warna urin pada Mahasiswa Ilmu Keolahragaan Universitas Negeri Medan. Oleh sebab itu peneliti mengambil kesimpulan untuk memperoleh judul penelitian yaitu "Pengaruh Pemberian Air Kelapa Muda Terhadap Tingkat Status Hidrasi Cairan Tubuh Setelah Melakukan Aktifitas Olahraga Mahasiswa Jurusan Ilmu Keolahragaan Universitas Negeri Medan”.

\section{Metode}

Berdasarkan rumus dan hipotesis penelitian, jenis dan rancangan penelitian ini termaksud dalam penelitian eksperimen lapangan dengan Quasi Experimental Design. Populasi dari penelitian ini adalah mahasiswa angkatan 2016 kelas A jurusan ilmu keolahragaan FIK UNIMED sebanyak 19 orang.

Teknik pengambilan sampel dalam penelitian ini menggunakan nonprobality sampel dengan cara porposive sampling.

Variabel Penelitian: (a) Variabel bebas(yang mempengaruhi): Pengaruh pemberian air kelapa muda, (b) Variabel terikat(yang dipengaruhi): Tingkat status hidrasi cairan tubuh. Bahan dan Instrumen Penelitian: (1) Air kelapa muda, (2) Air putih. Instrumen penelitian: (1) Peluit, (2) Alat tulis, (3) Stopwatch, (4) Gelas ukur

Lokasi dan Waktu Penelitian: Lokasi penelitian pada penelitian ini yaitu Lapangan Serbaguna Universitas Negeri Medan, jadwal penelitian dilaksanakan pada hari kamis 8 desember 2016.

Prosedur Penelitian: (1) Membagi subjek menjadi dua kelompok yaitu kelompok 1 (kelompok kontrol yaitu kelompok ini mengkonsumsi air putih) dan kelompok 2 (kelompok eksperimen yaitu kelompok ini mengkonsumsi air kelapa muda), (2) Memberikan penjelasan kepada calon subjek penelitian mengenai maksud dan tujuan penelitian, (3) Calon subjek melakukan pemanasan sebelum melakukan aktifitas olahraga lari 15 menit, (4) Aktifitas olahraga Lari 15 menit, (5) Kelompok kontrol dan eksperimen dilakukan pre-test setelah berlari 15 menit dengan pengambilan kadar urin, (6) Setelah dilakukan pre-test kadar warna urin selanjutnya dilakukan pemberian air putih dan air kelapa muda sebanyak $500 \mathrm{ml}$, (7) Setelah 
senggang waktu 15 menit setelah pemberian maka dilakukan post test pengukuran kadar warna urin terhadap kelompok kontrol dan kelompok eksperimen.

\section{Pembahasan}

Untuk memperoleh data dalam penelitian ini yaitu dengan pengukuran terhadap 14 sampel dari sejumlah sampel yang ada akan dilihat pengaruh pemberian air kelapa muda terhadap tingkat status hidrasi cairan tubuh setelah melakukan aktifitas olahraga mahasiswa ilmu keolahragaan Unuversitas Negeri Medan dari 14 sampel yang ada dibagi menjadi dua kelompok dengan cara matching pairing dengan 7 orang sampel menjadi kelompok Eksperimen dengan pemberian air kelapa muda dan 7 orang menjadi kelompok kontrol dengan pemberian air putih.

Untuk mengetahui pengaruhnya, pada kelompok eksperimen dan kelompok kontrol kedua kelompok melakukan aktifitas olahraga dengan berlari selama 15 menit selanjutnya dilakukan pengambilan sampel urin pada kedua kelompok sebelum pemberian air kelapa pada kelompok eksperimen dan air putih pada kelompok kontrol dan sesudah pemberian air kelapa pada kelompok eksperimen dan air putih pada kelompok kontrol. Lalu data yang dianalisis adalah data tes awal dan tes akhir kadar warna urin.

Setelah semua data yang diperoleh maka dilakukan perhitungan dengan statistik untuk mengetahui apakah memang benar ada Pengaruh Pemberian Air Kelapa Muda Terhadap Tingkat Status Hidrasi Cairan Tubuh Setelah Melakukan Aktifitas Olahraga Mahasiswa Jurusan Ilmu Keolahragaan Universitas Negeri Medan dan juga untuk mengetahui manakah lebih baik diantara perlakuan tersebut. Tabel. 1 Hasil Pre Test Dan Post Test Kelompok Eksperimen Dan Kontrol Terhadap Tingkat Status Hidrasi Cairan Tubuh.

\begin{tabular}{|c|c|c|c|c|}
\hline \multirow{3}{*}{$\begin{array}{l}\text { Deskripsi } \\
\text { Data }\end{array}$} & \multicolumn{4}{|c|}{ Respon Nadi Pemulihan } \\
\hline & \multicolumn{2}{|c|}{$\begin{array}{c}\text { Pemberian Air } \\
\text { Kelapa Muda } \\
\text { (Eksperimen) }\end{array}$} & \multicolumn{2}{|c|}{$\begin{array}{c}\text { Pemberian Air } \\
\text { Putih } \\
\text { (Kontrol) }\end{array}$} \\
\hline & Pre test & $\begin{array}{c}\text { Post } \\
\text { test }\end{array}$ & $\begin{array}{l}\text { Pre } \\
\text { test }\end{array}$ & $\begin{array}{c}\text { Post } \\
\text { test }\end{array}$ \\
\hline Rentang & $4-8$ & $1-2$ & $4-8$ & $3-6$ \\
\hline Nilai rata-rata & 6,14 & 1,57 & 6,42 & 4,42 \\
\hline $\begin{array}{l}\text { Simpangan } \\
\text { Baku }\end{array}$ & 2,19 & 0,53 & 1,44 & 2,23 \\
\hline $\begin{array}{l}\text { Uji Normalitas } \\
\text { Lo }\end{array}$ & 0,200 & 0,285 & 0,205 & 0,238 \\
\hline $\mathrm{L} \alpha=0,05$ & 0,300 & 0,300 & 0,300 & 0,300 \\
\hline $\begin{array}{l}\text { Uji } \\
\text { Homogenitas }\end{array}$ & \multicolumn{2}{|c|}{1,37} & \multicolumn{2}{|c|}{2,10} \\
\hline F table & \multicolumn{2}{|c|}{4,28} & \multicolumn{2}{|c|}{4,28} \\
\hline$t_{\text {hitung }}$ & \multicolumn{2}{|c|}{2,38} & \multicolumn{2}{|c|}{2,09} \\
\hline $\mathrm{t}_{\text {tabel }}$ & \multicolumn{2}{|c|}{1,94} & \multicolumn{2}{|c|}{1,94} \\
\hline Kesimpulan & \multicolumn{2}{|c|}{ Ada pengaruh } & \multicolumn{2}{|c|}{ Ada pengaruh } \\
\hline $\mathrm{t}_{\text {hitung }}$ & \multicolumn{4}{|c|}{3,31} \\
\hline $\mathrm{t}_{\text {tabel }}$ & \multicolumn{4}{|c|}{1,75} \\
\hline Kesimpulan & \multicolumn{4}{|c|}{ Ada perbedaan } \\
\hline
\end{tabular}


Pada kelompok pemberian air kelapa muda terhadap tingkat status hidrasi dengan pengukuran kadar warna urin diperoleh rentang antara 4-8 dengan rata-rata 6,14 dengan simpangan baku 2,19 dan hasil post test rentang antara 1-2 dengan ratarata 1,57 dengan simpanagn baku 0,53. Pada kelompok pemberian air putih terdapat tingkat status hidrasi dengan pengukuran kadar warna urin diperoleh rentang antara 48 dengan rata-rata 6,42 dengan simpangan baku 1,44 dari hasil post test rentang antara 3-6 dengan rata-rata 4,42 dengan simpangan baku 2,23.

\section{A. Pengujian Persyaratan Analisis}

- Uji normalitas

Pengujian terhadap normalitas sampel menggunakan uji Lilliefors dapat dilihar pada tabel dibawah ini (perhitungan lengkap terhadap lampiran).

Tabel 2. Ringkasan Hasil Uji Normalitas

\begin{tabular}{|c|c|c|c|c|}
\hline Kelompok & $\mathrm{N}$ & Lo & Lt & Kesimpulan \\
\hline $\begin{array}{c}\text { Pre Test } \\
\text { Eksperimen }\end{array}$ & 7 & 0,200 & 0,300 & Normal \\
\hline $\begin{array}{c}\text { Post Test } \\
\text { Eksperimen }\end{array}$ & 7 & 0,285 & 0,300 & Normal \\
\hline $\begin{array}{c}\text { Pre Test } \\
\text { Eksperimen }\end{array}$ & 7 & 0,205 & 0,300 & Normal \\
\hline $\begin{array}{c}\text { Post Test } \\
\text { Eksperimen }\end{array}$ & 7 & 0,238 & 0,300 & Normal \\
\hline
\end{tabular}

Pada tabel diatas harga $\mathrm{L}_{\text {obserfasi }}$ untuk semua kelompok lebih kecil dari pada $\mathrm{L}_{\text {tabel, }}$ sehingga dapat di simpulkan bahwa data hasil setiap kelompok berasal dari populasi yang berdistribusi normal.

- Uji Homogenitas

Pengujian homogenitas varians populasi dilakukan dengan menggunakan uji varians besar dibagi varians kecil dapat dilihat pada tabel dibawah ini (perhitungana lengkap terdapat pada lampiran).

Tabel 3. Ringkasan Hasil Uji Homogenitas

\begin{tabular}{|c|c|c|c|}
\hline Sampel Penelitian & $\mathrm{F}_{\text {hitung }}$ & $\mathrm{F}_{\text {tabel }}$ & Kesimpulan \\
\hline $\begin{array}{c}\text { Pre test dan Post } \\
\text { test Kelompok } \\
\text { Eksperimen }\end{array}$ & 1,37 & 4,28 & Homogen \\
\hline $\begin{array}{c}\text { Pre test dan Post } \\
\text { test Kelompok } \\
\text { Kontrol }\end{array}$ & 2,10 & 4,28 & Homogen \\
\hline
\end{tabular}

Pada tabel diatas dapat dilihat bahwa harga $\mathrm{F}_{\text {hitung }}<\mathrm{F}_{\text {tabel }}$, sehingga dapat disimpulkan bahwa data kadar warna urin memiliki varians populasi yang homogen. Pengujian Hipotesis

1. Pengujian Hipotesis I

Berdasarkan hasil perhitungan yang dilakukan, maka diperoleh pengujian hopotesis sebesar $\left(\mathrm{T}_{\text {hitung }}\right)$ 2,38 selanjutnya harga tersebut dibandingkan dengan harga $\mathrm{T}_{\text {tabel }}$ dengan $\mathrm{dk} \mathrm{n}-1(7-1=6)$, pada taraf signifikan $\alpha=0,05$ adalah 1,94 dengan 
demikian $t_{h}>t_{t}(2,38>1,94)$, maka Ho ditolak dan Ha diterima yang menyatakan terdapat Pengaruh Pemberian Air Kelapa Muda Terhadap Tingkat Status Hidrasi Cairan Tubuh Setelah Melakukan Aktifitas Olahraga Mahasiswa Jurusan Ilmu Keolahragaan Universitas Negeri Medan.

2. Pengujian Hipotesis II

Berdasarkan hasil perhitungan yang dilakukan, maka diperoleh pengujian hipotesis sebesar $\left(\mathrm{T}_{\text {hitung }}\right.$ ) 2,09 selanjutnya harga tersebut dibandingkan dengan harga $\mathrm{T}_{\text {tabel }}$ dengan dk $\mathrm{n}-1(7-1=6)$, pada taraf signifikan $\alpha=0,05$ adalah 1,94 demikian $\mathrm{t}_{\mathrm{h}}$ $>\mathrm{t}_{\mathrm{t}}(2,09>1,94)$, ), maka Ho ditolak dan Ha diterima yang menyatakan terdapat Pengaruh Pemberian Air Putih Terhadap Tingkat Status Hidrasi Cairan Tubuh Setelah Melakukan Aktifitas Olahraga Mahasiswa Jurusan Ilmu Keolahragaan Universitas Negeri Medan.

\section{Pengujian Hipotesis III}

Untuk mengetahui perbedaan pengaruh pemberian air kelapa muda dengan air putih setelah melakukan aktifitas olahraga kemudian diberikan perlakuan pengujian hipotesis post test. Kriteria pengujian adalah : terima $\mathrm{Ha}$ jika $\mathrm{T}_{\text {hitung }}>\mathrm{T}_{\text {tabel }}$, dimana $\mathrm{T}_{\text {tabel }}$ didapat dari daftar distribusi t dengan $\mathrm{dk}=\left(\mathrm{n}_{1}+\mathrm{n}_{2}-2\right)$. Diperoleh bahwa $\mathrm{T}_{\text {hitung }}$ sebesar 3,31. Dari daftar tabel $\mathrm{dk}=(7+7-2)$ diperoleh bahwa $\mathrm{T}_{\text {tabel }}=1,75$. Dengan demikian $\mathrm{T}_{\text {hitung }}>\mathrm{T}_{\text {tabel }}(3,31>1,75)$ dengan demikian $\mathrm{Ho}=$ ditolak dan $\mathrm{Ha}=$ diterima yang menyatakan Pemberian Air Kelapa Muda Lebih Baik Pengaruhnya Terhadap Tingkat Status Hidrasi Cairan Tubuh Dibandingkan Dengan Air Putih Setelah Melakukan Aktifitas Olahraga Mahasiswa Jurusan Ilmu Keolahragaan Universitas Negeri Medan

Dari uraian diatas disimpulkan bahwa Air Kelapa Muda Secara Signifikan Mempengaruhi Tingkat Status Hidrasi Mahasiswa Jurusan Ilmu Keolahragaan Universitas Negeri Medan Setelah Melakukan Aktifitas Olahraga hal ini juga diperkuat dari rata - rata pemberian air kelapa muda lebih baik dibandingkan tanpa air kelapa muda. Cairan tubuh merupakan komponen terbesar dalam tubuh, yang jumlahnya mencapainya mencapai $60 \%$ dari total berat badan yang berdistribusi dalam cairan ekstrasel $24 \%$ dan cairan intrasel $36 \%$. Jumlah tersebut sangat berfariasi tergantung pada umur, jenis kelamin dan jumlah lemak dalam tubuh.

Cairan tubuh juga berfungsi dalam mengatur temperatur tubuh melalui evaporasi (penguapan). Cairan tubuh merupakan larutan, yaitu campuran homogenik dari dua zat atau lebih. Cairan tubuh tersebut terdapat didalam air kelapa muda. Air kelapa adalah sari pati buah kelapa muda yang merupakan minuman bergizi dan menyegarkan dan pemanfaatannya seri dilakukan masyarakat sebagai minuman bergizi dan menyagarkan. Air kelapa sering di manfaatkan masyarakat sebagai pengganti cairan tubuh. Namun masyarakat tidak banyak mengetahui manfaat besar yang terdapat didalam air kelapa muda tersebut. Padahal air kelapa muda sangat baik bagi kesehatan tubuh manusia.

Kandungan elektrolid dan glukosadalam air kelapa muda bersifat isotonik sehingga sangat baik diminum sebagai cairan rehidrasi pengganti cairan yang hilang saat melakukan aktifitas seperti aktifitas olahraga. Komposisi kandungan dari air 
kelapa muda adalah gula sebanyak 4,4mg\%, natrium $42 \mathrm{mg} \%$, kalium $29 \mathrm{mg} \%$, kalsium 44mg\%, magnesium 10mg\%, besi $106 \mathrm{mg} \%$, dan tembaga $26 \mathrm{mg} \%$.

Selain glukosan dan elektrolit, air kelapa juga mengandung vitamin dan protein yang sangat diperlukan oleh tubuh. Protein merupakan komponen penyusun membran sel dan organel, berfungsi dalam membentuk jaringan enzim dan hormon, dan cadangan energi. Terdapat 12 asam amino penting yang terdapat dalam air kelapa muda antara lain alanin, argin, asam aspartat, asam glutamat, histidin, fenilalanin, tirosin, dan lain - lain. Jenis fitamin yang terdapat dalam air kelapa muda adalah vitamin B, yang merupakan koenzim dalam metabolisme sumber energi baik, karbohidrad, lemak maupun protein, dan pembentukan sel. Terdapat 7 jenis vitamin B yang terdapat dalam air kelapa muda yaitu asam nikotinik, asam pattotenat, biotin, riboflavin (B2), asam folat, tiamin(B1) dan pridoksin (B6). Kandungan glukosa, elektrolit, vitamin, dan protein menyebabkan air kelapa bukan saja berfungsi sebagai pengganti cairan dalam tubuh tetapi juga sebagai sumber energi dan untuk mempercepat fase pemulihan setelah beraktifitas olahraga.

Bojonegoro (2009) mengemukakan bahwa "jumlah kalium dalam tubuh sekitar $53 \mathrm{mEq} / \mathrm{kg}$ berat badan”. Dari pendapat ahli tersebut dapat disimpulkan bahwa kadar potasium yang tinggi dalam air kelapa muda jika dikonsumsi maka akan berfungsi untuk meningkatkan sistem kekebalan tubuh serta badan lebih segar dan fit. Kalium sangat diperlukan oleh mahluk hidup. Unsur ini merupakan kation utama didalam cairan intraseluler dan berperan penting dalam terapi gangguan keseimbangan air dan elektrolit. Konsentrasi kalium yang terlalu tinggi atau terlalu rendah dapat meyebabkan timbulnya masalah yang serius, seperti irama jantung yang abnormal. Kalium yang disimpan didalam sel membantu memelihara konsentrasi kalium dalam darah agar tetap konstan. Keseimbangan kalium dijaga dengan menyesuaikan jumlah asupan kalium dalam makanan dengan jumlah kalium yang dibuang. Sebagian besar kalium dibuang melalui air urine. Ketika volume urine dikeluarkan dalam jumlah banyak, maka urine hanya akan dilarutkan dalam voolume cairan dalam jumlah yang besar pula sehingga urin akan berwarna lebih terang. Namun, ketika volume urine dikeluarkan dalam jumlah sedikit maka urin akan pekat dan berwarna gelap. Itu diakibatkan saat aktifitas olahraga tubuh kita kekurangan cairan sehingga volume urin yang dikeluarkan akan semakin sedikit dan berwarna pekat.

Dari uraian diatas dapat disimpulkan bahwa air kelapa muda dapat digunakan sebagai cairan elektrolit alami atau cairan olahraga alami, khususnya saat setelah melakukan aktifitas olahraga. Air kelapa sangat berpengaruh terhadap pemulihan status hidrasi karena banyak mengandung cairan elektrolit berupa kalium dan natrium sehingga pengaruhnya dapat dilihat melalui status kadar warna urine.

\section{Simpulan}

Pemberian Air Kelapa Muda Lebih Baik Pengaruhnya Terhadap Tingkat Status Hidrasi Cairan Tubuh Dibandingkan Dengan Air Putih Setelah Melakukan Aktifitas Olahraga Mahasiswa Jurusan Ilmu Keolahragaan Universitas Negeri Medan 


\section{Rujukan}

Sudjana, 2009. Metode Statistik, Tarsito, Bandung.

Sugiyono, 2015. Metode Penelitian Pendidikan, Alfa beta, Bandung

Anwar Irawan, 2007. Cairan Tubuh, Elektrolit dan Mineral. Sport Science Brief, Vol.01 No 1, Halaman 1.

Dwita, L.P, 2009. Pengaruh Rehidrasi Dengan Air Kelapa (Cocos Nutifera L) dan Minuman Suplemen Terhadap Stamina Atlet. Skripsi, Sekolah Farmasi ITB.

Eko Andi Susilo, 2015. Pengaruh Konsumsi Air Kelapa Muda Terhaddap Waktu Reaksi Setelah Melakukan Interval Training, jurnal kesehatan vol.03 oktober.

Vilanata, 2015. Pentingnya Pemeriksaan Status Hidrasi Sebelum Aktivitas Fisik Pada Atlet. (file:///C:/Users/LINGGA/Documents/Pentingnya Pemeriksaan Status Hidrasi Sebelum Aktivitas Fisik Pada Atlet _ First Sports Nutrition Consulting.htm)Pemeriksaan Status Hidrasi, Diakses Pada Tanggal 5 November 2015

Kemala, D.C.B., and M.Velayutham, 1978. Changes In The Chemical Composisi Of Nut Water And Kernel During Develodmen Of Coconut. Placrosy1:340 346.

Lavizzo-Mourey, RJ, 1987. Dehydration in the Elderly: A Short Review. Journal of the National Medical Association, Vol. 79, No. 10.

Men'Health, 2015. Kandungan Gizi Air Kelapa. http://www.menshealth.co.id / nutrisi /nutrisi. umum/kandungan.gizi.air.kelapa/003/002/138. Diakses pada tanggal 10 April 2014.

Thomas, 2014. Perbedaan Pengaruh Pemberian Air Kelapa Muda Dengan Air Mineral Terhadap Respon Denyut Nadi Pemulihan Setelah Melakukan Latihan Fisik Pada Atlet Perguruan Silat Garuda Sakti Kec. Biru - Biru Tahun 2013.. 